
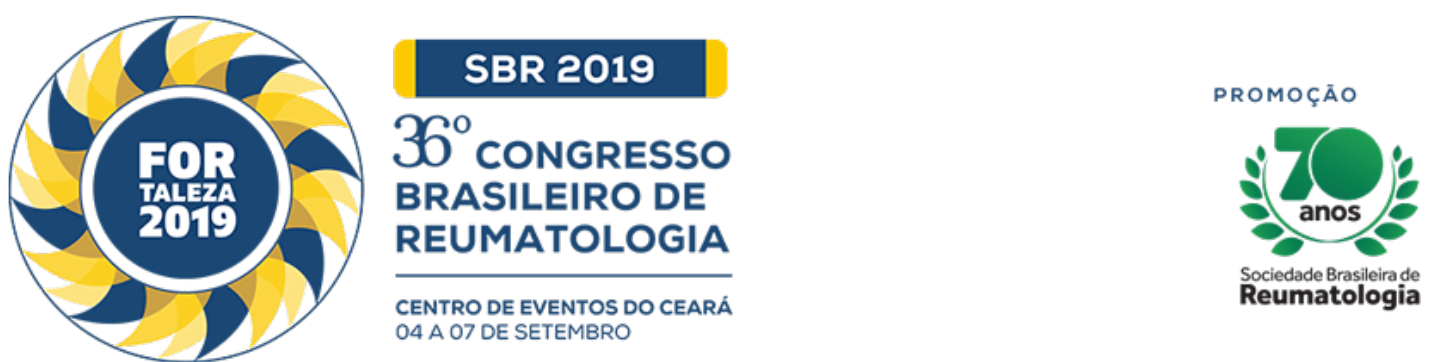

\title{
COULD BELIMUMAB BE AN ALTERNATIVE FOR REFRACTORY THROMBOCYTOPENIA IN PATIENTS WITH SLE? - CASE REPORT
}

LUMA MENDES BRITO (USP, SAO PAULO, SP, Brasil), CAMILA DA SILVA CENDON DURAN (USP, SAO

PAULO, SP, Brasil), MICHELLE REMIÃO UGOLINI LOPES (USP, SAO PAULO, SP, Brasil), BRUNA KELLEN

PORTO (USP, são paulo, SP, Brasil), Rodrigo da Silveira Vasconcelos (USP, São Paulo, SP, Brasil)

\section{BACKGROUND}

B cells play a crucial role in the pathogenesis of SLE (systemic lupus erythematosus). B lymphocyte stimulator levels (BLyS) are correlated with anti-dsDNA antibody levels and disease activity in SLE. Belimumab is a human monoclonal antibody that binds to BLyS preventing its binding to B-cell receptors and it is indicated for cutaneous-articular manifestations. This study reports a case of SLE thrombocytopenia refractory to conventional immunosuppressive therapies and rituximab, that might have responded to Belimumab.

\section{CASE REPORT}

GSS, Female, 32 years old, white and previously healthy, diagnosed SLE in 2004 with cutaneous, articular, hematological involvement, in addition to homogenous FAN 1/320 and Anti-DNA positive. Patient started treatment outside of our service with prednisone $60 \mathrm{mg}$ and Hydroxychloroquine $400 \mathrm{mg}$. In 2010, the platelet count was 9,000 platelets $/ \mathrm{mm} 3$, and monthly pulse therapies with metiprednisolone were indicated, and for the maintenance oral prednisone was prescribed. After the pulses, the platelets count responded but never sustained above 50,000 platelets $/ \mathrm{mm} 3$. Azathioprine was associated, but the patient got intolerant. Dapsone was also tried, but the patient developed skin allergy. Due to intolerances she received 2 cycles of Rituximab, the last one in June 2017 without recover of platelets levels. She was referred to our service in early 2018 with 19,000 platelets / $\mathrm{mm} 3$ and complaining of frequent hematomas, and in the first visit the recorded SLEDAI-2K was 9 (alopecia, anti-DNA, thrombocytopenia, serositis, and low complement levels). The platelet count was confirmed with citrate and EDTA tube, manual counting and warm tube. Other causes of thrombocytopenia such as chronic infections, bone marrow diseases and hypersplenism were excluded. The only possible confusion factor remining was a single time lupus anticoagulant positive. We prescribed mycophenolate, unsuccessfully. In the end of February 2019, we indicated Belimumab with a good response after the third attack dose, with 111,000 platelets / $\mathrm{mm3}$.

\section{CONCLUSION}

SLE thrombocytopenia is not a label-indication of Belimumab, and literature lack studies regarding its' safety and efficacy in severe thrombocytopenic patients. We described a good response of a refractory thrombocytopenia after attack dose of Belimumab, we still need more follow-up visits to understand if this response will be sustained. 